\title{
Management of Sarcopenia in Elderlies
}

\section{Yaşlı Bireylerde Sarkopeninin Yönetimi}

\author{
Hakan Yaman ${ }^{1}$, Ramazan Vural $^{* 2}$
}

\begin{abstract}
Improvement in living conditions, science and technology has enabled the management of several diseases. However, in elderly people new medical condition, which cannot be explained by other definitions of disease are evolving. These are called geriatric syndromes. Sarcopenia might be one of these syndromes. Commonly it is defined as loss of muscle mass and functionality due to aging. Changes of the body composition, significant decline of the muscle mass and functions due to aging leads to decrease of physical performance, loss of strength, immobility, falls, and physical disability. An interdisciplinary approach is needed for the diagnosis and management of frailty. The diagnosis is based on the evaluation of the muscle mass, muscle strength, and physical performance of the patients by different methods and tests. The management process begins with the diagnosis and could be divided into two parts: non-pharmacological (physical activity and nutritional support) and/ or pharmacological management. Potential drugs, which are under development do not fulfill our expectations, because they are lacking any scientific evidence. Data on mechanism, effectivity, and safety are still missing. Therefore, nonpharmacological methods like sports and nutrition are sustaining their importance. Management approaches to sarcopenia should develop and facilitate sportive exercise and nutritional support programs. Family physicians play an important role during the care of this specific risk group. They might play an important at the early diagnosis, the follow-up and coordination of the care of this condition.
\end{abstract}

Key words: Geriatric syndrome, frailty, sarcopenia, family practice

\section{ÖZET}

Yaşam koşullarının iyileşmesi ile bilim ve teknolojideki gelişmeler, birçok hastalığın yönetimini olanaklı kılmaktadır. Bu çerçevede, yaşlı bireylerin sayıları artmaktadır. Yaşlı hastada, çoğunlukla atipik semptomlarla kendini gösteren ve hastalık tanımı ile açıklanamayan klinik durumları tanımlamak için, geriatrik sendrom terimi kullanılmaktadır. Bu terim, yaşlı hastalarda sık görülen, yaşam kalitesini bozup, morbidite ve mortaliteyi arttırabilen klinik durumları ifade etmektedir. Bu sendromlar arasında sarkopeniyi de saymak mümkündür. Yaygın tanımı ile sarkopeni, yaşlılığa bağlı kas kütlesi ve fonksiyon kaybını ifade eder. Yaşlanmayla beden bileşiminde oluşan değişiklikler, kas kütlesi ve işlevlerindeki anlamlı kayıplar ile bedensel verimde azalmalara, güç kaybına, bedensel bağımlılığa, düşmelere ve bedensel engelliliğe neden olmaktadır. Sarkopeni'nin tanısı ve tedavisi interdisipliner yaklaşım gerektirmektedir.Tedavi süreci tanının konulması ile başlamaktadır. Tanı kas kütlesinin, kas gücünün ve fiziksel performansın değiş̧ik yöntem ve testlerle değerlendirilmesi sonucu konulmaktadır.Sarkopeni’nin yönetimini non-farmakolojik (Bedensel Etkinlik ve Nütrisyonel Destek) ya/ ya da ilaç tedavileri olarak iki gruba ayırmak mümkündür. Geliştirilmeye başlanan potansiyel ilaçların kanıt eksiklikleri nedeniyle, henüz beklentilerimizi karşılayabilecek nitelikte olmadıkları anlaşılmaktadır. İlaç tedavilerinin mekanizması, etkinliği ve güvenliği ile ilgili veriler henüz yeterli değildir. Bu nedenle, spor ve nütrisyonel destek gibi non-farmakolojik tedavilerin önemi sürmektedir. Yaklaşımında ise, planlama ve uygulama bakımından sarkopenili bireye özel sporsal alıştırma ve beslenme destek planları geliştirilmeli ve uygulamaya konulmalıdır. Aile hekimlerinin, bu risk grubunun bakımında önemli rolü bulunmaktadır. Sorunun erken tespitinde rol alabileceği gibi, bakımın takibinde ve koordinasyonunda ilgili uzmanlık dallarına desteği mümkündür.

Anahtar kelimeler : Geriatrik sendrom, düşkünlük, kırılganlık, sarkopeni, aile hekimliği

Received / Geliş tarihi: 26.03.2016, Accepted / Kabul tarihi: 25.06.2016

${ }^{1}$ Akdeniz Üniversitesi Tıp Fakültesi Aile Hekimliği Anabilim Dalı

${ }^{2}$ Antalya Eğitim ve Araştırma Hastanesi Aile Hekimliği Kliniği

*Address for Correspondence / Yazışma Adresi: Ramazan Vural, Antalya Eğitim ve Araştırma Hastanesi Aile Hekimliği Kliniği, AntalyaTÜRKIYE,

E-mail: ramazanvural@yahoo.com

Vural R, Yaman H. Yaşlı Bireylerde Sarkopeninin Yönetimi. TJFMPC, 2016;10(4): 243-249.

DOI: $10.21763 /$ tjfmpc.271330 


\section{GíRiş}

Yaşam koşullarının iyileşmesi ile bilim ve teknolojideki gelişmeler birçok hastalığın yönetimini olanaklı kılmaktadır. $\mathrm{Bu}$ çerçevede yaşlı bireylerin sayıları artmaktadır. Bu artış aile hekimlerinin gündelik pratiklerini de etkilemektedir. Geçmişte yaşlı bireylere ilişkin sağlık sorunları ile nispeten nadiren karşılaşılırken, şu anda gündelik rutinlerinin bir parçası haline gelmiştir. $\mathrm{Bu}$ sorunlardan bazılarına da "Geriatrik Sendrom" adı verilmektedir. Şahin S ve ark. göre geriatrik sendrom yaşlı hastalarda sıklıkla tipik olmayan yakınmalarla ortaya çıkan ve belirli bir hastalık grubuna dahil edilemeyen klinik bir tablo ya da yakınma olarak ifade edilmektedir. ${ }^{1}$ Inouye SK ve ark. ise bu durumu yaşlılarda sık görülen emsalsiz bir durum olarak ifade etmektedirler ve deliryum, düşmeler, inkontinans ve düşkünlügü bu kapsamda ele almaktadırlar. ${ }^{2}$

Sarkopeni ise, düşkünlük (kırılganlık) olarak adlandırılan geriatrik sendromun bir parçasıdır. $\mathrm{Bu}$ çerçevede, geriatrik bir sendrom olarak ele alınması olasıdır. Sarkopeni terimi Grekçe'den dilimize kazandırılmıştır; "sarx (kas)" ve "penia (kayıp)" kelimelerinden türetilmiştir. ${ }^{3}$ Genel anlamda yaşlılığa bağlı kas kütlesi ve işlev kaybı olarak ifade edilebilir. ${ }^{4}$ Sarkopeniye, genellikle oturganlık (bedensel inaktivite), hareketlilikte azalma, yürümede yavaşlama ve bedensel dayanıklılıkta azalma eşlik etmektedir. ${ }^{5}$ Avrupa Geriatri Derneği (EUGMS)'in kriterlerine göre sarkopeni, ilerleyici ve genel kas kütlesi ve kuvvet kaybı ile giden bir sendrom olarak tarif edilmektedir. Bu sendrom, bedensel engellilik, kötü yaşam niteliği ve mortalite gibi riskler barındırmaktadır. Avrupa Yaşlı Bireylerde Sarkopeni Çalışma grubu (EWGSOP) ise, sarkopeni tanısında kas kütle kaybı artı kas kuvveti kaybı ya da fiziksel performans kaybının ölçümünü ya da belgelenmesini önermektedir. $\mathrm{Bu}$ tanıma, kuvvet kaybının sadece kas kütlesi kaybına bağlı olmamas1 nedeniyle gerek duyulmuştur. Sarkopeni teriminin yaygın kullanımı, dinapeni gibi bu duruma daha uygun düşen isimlendirmenin kullanımını engellemiştir. ${ }^{6}$ Sarkopeni, sıklıkla yaşlı bireylerin sorunu olmakla birlikte, genç bireylerde de immobilite, malnütrisyon ve kaşeksi gibi durumlara bağlı gelişebilmektedir. Sarkopeni, kaşeksiden ayırt edilmelidir. Kaşeksi, altta yatan hastalığa ve yangıya bağlı gelişen; beslenme desteğine zor yanıt veren, istem dışı kilo kayb1 ile seyreden kompleks bir sendromdur. ${ }^{7}$ Sarkopeni'nin tespiti ve tanımlanmasına ilişkin muhtelif yöntemler bulunmakla birlikte, yaşa bağlı olarak, kas kütlesinin azaldığ 1 kabul edilmektedir. Yetmiş yaşında olan bireylerin birçoğu, 20-30 yaşlarında bulunanların kas kütlesinin tahminen \%80'ine sahip iken, yıllık \%0.5-1 oranında kas kütlesi kaybına maruz kalacaklardır. ${ }^{8}$

Hastalığın tanısı ve tedavisi, interdisipliner yaklaşım gerektirmektedir. Gerek günlük pratikte karşılaşılan hastaların tanılarının doğru konulabilmesi, gerekse düzenlenen tedavilerin takibinde aile hekimleri multidisipliner ekibin önemli bir parçasıdır.
Sarkopeni'nin yönetimi, tanının konulması ile başlamaktadır. Tanının doğru konulması önem arz etmektedir ve kas kütlesinin, kas gücünün ve fiziksel performansın değişik yöntem ve testlerle değerlendirilmesi sonucu konulmaktadır. Yönetiminin en uygun biçimde planlamasını yapabilmek için, sarkopeni mekanizmasının kısaca gözden geçirilmesi faydalı olacaktır.

Sarkopeniyi tetikleyebilecek ya da sürmesine neden olabilecek olası farklı açıklamalar bulunmaktadır: Proteinenerji malnütrisyonu, protein sentezi, proteoliz, nöromusküler bütünlük ve kas yağı içeriği. ${ }^{9}$

Kas kütlesindeki azalma, kas liflerindeki azalma ve kas liflerinin atrofisinin kombinasyonuyla oluşur. Motor ünitelerinde gelişen denervasyon ve yavaş motor ünitelerinin reinnervasyonu kas yorgunluğunun artmasına neden olmaktadır., ${ }^{9,10}$ Tip I kas liflerinin artışı söz konusudur. Yaşlanmayla birlikt,e satelit hücre sayılarındaki azalma, kas rejenerasyonunu etkileyecek ve sarkopeni'nin gelişimini kolaylaştıracaktır. ${ }^{9,11}$

IGF-1 ve androjen düzeyleri yaşla birlikte azalmakta ve kas gelişimini olumsuz etkilemektedir. Anjiyotensin II'nin kas zayıflığ 1 ve düşük IGF-1 seviyeleri ve insülin direnci ile ilişkili olduğu düşünülmektedir. ${ }^{9,12}$ Yaşlanan bireylerde proinflamatuvar sitokin, TNF- $\alpha$ ve IL-6 düzeylerinin artış gösterdikleri saptanmıştır. ${ }^{9,13}$

Sarkopeni yönetimini, non-farmakolojik ve ilaç tedavisi olarak iki gruba ayırmak mümkündür:

\section{A. NON-FARMAKOLOJIK TEDAVILER}

Egzersiz ve Bedensel Etkinlik : Dayanıklılık, kuvvet ya da kombine alıştırmalar

Nütrisyonel Destek: Protein, amino asit ve metabolitleri, esansiyel yağ asitleri, vitaminler

\section{B. İLAÇ TEDAVIILERI}

Anjiotensin-Converting-Enzim İnhibitörleri (ACE İnhibitörleri), Statinler, Testosterone, Dehydroepiandrosterone (DHEA), Kreatin, Selektif Androjen Reseptör Modülatörleri

\section{A) NON- FARMAKOLOJIK TEDAVIILER}

Sarkopeni'nin iyileşmesinde, en güçlü ve güvenli etken bedensel etkinlik, yaşam tarzı değişiklikleri ve kişiye özel nütrisyonel destektir. ${ }^{14,15,16,17}$

Sarkopenide kuvvet kaybının kas kütlesi kaybı ve protein sentez yetersizliğine; dayanıklılıkta azalmanın ise mitokondri sayısının azalması ve buna bağlı mitokondriye 
bağlı aerobik enzim yetersizliğine bağlı olduğu düşünülmektedir. Düzenli bedensel etkinliğin genel yaşam süresini arttırdığı, bedensel güçsüzlük ve kronik hastalık gelişim riskini azalttığı, sedanter yaşam tarzı üzerinde iyileştirici fizyolojik etkisinin olduğu gösterilmiştir. ${ }^{18}$ Yaşlılarda, bedensel etkinliğine bağlı riskleri azaltmak için, uygulanacak bedensel etkinlik tipini anlaşılır biçimde belirlemek gerekir. ${ }^{19}$

Bedensel etkinlik tipleri, dayanıklılık alıştırmaları, kuvvet alıştırmaları ve kombine olmak üzere üç türdür. Yaşları 60-80 arasında olan bireylerde, uygun alıştırmalarla, dayanıklılıklarında \%20-30 oranında artış sağlanabileceği gösterilmiştir. Dayanıklılık alıştırmalarında, geniş kas grupları belirli sürelerle ritmik olarak hareket ettirilir (yürümek, tempolu yavaş koşma, bisiklete binmek gibi). Kuvvet çalışmalarında da uygun yüklenme protokollerine yer verildiği taktirde, genç bireylere benzer kuvvet artımlarına erişilebileceği bildirilmektedir. Kuvvet alıştırmaları ise, serbest ağırlıklarla yapılır (ağırlık kaldırma, halter gibi). ${ }^{20}$ Dayanıklılığa bağlı yüklenmelerin, kas kütlesi ve gücünün iyileşmesi üzerine az etkisi vardır. ${ }^{21}$ Kuvvete dayalı alıştırmalar, kas kütlesini artırır ve gücünü iyileştirir. Kuvvet alıştırmaları, yaşlılarda bedensel fonksiyonlarda düşüşü önlemek ve tüm nedenlere bağlı mortaliteye karşı korumak amacıyla sarkopeni için daha spesifik bulunmuştur. ${ }^{22,23}$ Progresif kuvvet çalışmaları, yaşlı bireylerde en sık kullanılan alıștırma türüdür. Bir sistematik gözden geçirmeye göre, yüksek yoğunlukla yüklenme yapılan yaşlı bireylerin kondisyonel yetilerinde olumlu değişiklikler gözlenmiştir. Sarkopenide, değiştirilebilir ana risk faktörü oturgan (sedanter) yaşam tarzıdır. Yaşlılar için, mevcut tıbbi durumları doğrultusunda bireysel hedefler belirlenerek en uygun alıştırma türü, yoğunluğu, şiddeti ve kapsamı seçilmelidir. Dayanıklılık ve kuvvet alıştırmaları kombine edilerek, düzenli yapılmalıdır. Haftada, en az üç gün, günaşırı dayanıklılık ve ara günlerde kuvvet çalışmalarına yer verilmelidir. Yapılan yüklenmelerin dozu önemli olduğu gibi, yüklenme öncesi ısınma ve yüklenme sonrası soğumaya firsat tanınmalıdır.

\section{Terapötik Spor Uygulamalarına İlişkin Genel Öneriler:}

Yavaş yavaş başlayın: Yaralanma riskini en aza indirmek için, her türlü faaliyete düşük yoğunlukta ve kısa sürelerle başlanmalıdır. Alıştırmalar etkin olmadığı taktirde, çalışma programı yeniden gözden geçirilmelidir. Yüklenmelere bağlı bir adaptasyonun gelişebilmesi için, en az 8-12 hafta düzenli spor yapmış olmak gerekir.

Isınma ve soğuma: Bedensel etkinlik öncesi (1sınma) ve sonrası (soğuma) özellikle yaşlılar için çok önem arz eder. $\mathrm{Bu}$ alıştırmalar, kişinin kalp atış hızı ve/veya solunumuna göre değiştirilmelidir. Örneğin, dayanıklılık çalışmalarından önce, ısınma kısa aralıklı düşük yoğunluklu hareketler içerebilir (5 dakika yürüyüş gibi).
Dayanıklılık çalışmaları için, yaşlılar günde 30-60 dakika orta yoğunlukta (150-300 dakika/hafta), ya da en az 20-30 dakika şiddetli yoğunlukta (75-150 dakika/hafta) bedensel etkinlik gerçekleştirmek için teşvik edilmelidirler. Alıştırmaların haftada en az üç gün yapılması önerilir. Hızlı yürüyüş, yüzme ve bisiklete binme gibi etkinlikler genellikle düşkün olmayan yaşlı bireylerde tolere edilebilir. $^{24}$

Spor alıştırmalarında, haftada iki veya daha fazla ardışık olmayan günlerde, 1lımlı (zorlama derecesi 10 üzerinden 56) 8-10 alıştırmadan oluşan tek bir setten, güçlü (zorlama derecesi 10 üzerinden7-8) 8-12 alıştırmaya kadar izin verilir. $^{25,26}$ Esneklik alıştırmaları, haftada en az iki gün, günde 10 dakika 1lımlı yüklemelerden başlayıp, yoğun alıştırmalar kapsamında doğru boyun, omuz, dirsek, el bileği, kalça, diz ve ayak bileği alanlarını kapsayan alıştırmaların yapılması önerilebilir. ${ }^{26}$

\section{Nütrisyonel destek}

Yaşlılıkta azalmış protein, vitamin D ve uzun zincirli poliansatüre yağ asidlerinin alımı, azalmış kas kütlesi işlevi ile ilişkilendirilmiştir. Sarkopeni anoreksi, azalmış kalori alımı ve kilo kaybı ile ilişkilidir. ${ }^{27} \mathrm{Bu}$ da azalmış kas kütlesi ve artmış mortalite ile ilişkilidir. Bu gerçekler, çoklu tedavi yaklaşımlarının bir parçası olarak, dengeli kalorik desteğin sarkopeni'nin önlenmesi ve iyileştirilebilmesi için yararlı olabileceğini göstermektedir. Bir çok çalışma ve 2 metaanaliz nütrisyonel desteğin, malnütrisyonlu ve/veya hasta yaşlilarda olumlu etkilerinin olduğunu göstermiştir. ${ }^{28,29}$

\section{Protein}

Sarkopeni, gücü asıl üreten tip II iskelet kas liflerinin atrofisi ile ilişkilidir. Kas yapısı ve fonksiyonu ise, kas protein yapımı ile ilişkilidir. Yetersiz nütrisyonel alım, emilim sonrası protein sentezindeki bozukluk ve besinlere özellikle amino asitlere hatalı cevap gibi bazı faktörler kas protein sentez kaybına neden olabilir. ${ }^{30}$

Son zamanlarda yapılan çalışmalar, önerilen 0.8 $\mathrm{g} / \mathrm{kg} /$ gün protein alımının, sağlıklı yaşlı insanlar için yeterli olmadığını düşündürmektedir. Optimal sağlık durumunu güvence altına almak için, protein alımı 1.2-1.3 g/ $\mathrm{kg} / \mathrm{gün}$ şeklinde artırılmalıdır. $1.5 \mathrm{~g} / \mathrm{kg} / \mathrm{gün}$ düzeyinde bir protein alımı, özellikle yaşlılıktaki inaktif dönemlerde önerilir. ${ }^{31}$ Elde edilen bulgular yüksek dozlarla karşılaştırıldığında, düşük doz protein alımının kas protein sentezini uyarmadığını teyit etmektedir. ${ }^{32}$

\section{Lösin}

Esansiyel amino asit (EAA) olan lösin, kas metabolizmasını düzenler. Lösin, iskelet kas protein sentezi için gerekli olan mRNA çevirisi ile ilgili, lösin etkileri düzenleyicisi olan rapamisin (mTOR), memeli hedef 
üzerinden kas anabolizmayı stimüle eder. Lösin, iskelet kas yıkımını azaltarak proteolitik mekanizmalar ile etkileşir. $^{33,34} \mathrm{Bu}$ veriler, lösin desteğinin sarkopeni tedavisinde etkili bir yaklaşım olabileceğini göstermektedir, ancak ileri çalışmalara ihtiyaç vardır. ${ }^{34}$

\section{Beta hidroksi beta metil butirat (HMB)}

Son zamanlarda, beta hidroksi beta metil butirat (HMB), sitrulin malat, ornitin alfa-ketogluterat gibi diğer amino asitler veya metabolitlerine kas protein sentezi üzerine etkilerileri nedeniyle giderek artan bir ilgi vardır. HMB'nin tek başına veya diğer amino asitlerle kombine olarak, yaklaşık $\% 20$ oranında proteini arttırdığ 1 gösterilmiştir. ${ }^{35}$ Bulgular, HMB'nin yaşlı sarkopenili hastalarda güvenli ve kullanışlı bir nütrisyonel destek olduğunu göstermektedir.

\section{Esansiyel yağ asitleri}

Omega-3 yağ asidinin, sarkopeninin tedavisinde olas1 yararları olabileceği düşünülmektedir. ${ }^{36}$ Yaşl1 3000 kişi ile yapılan bir çalışmada yüksek oranda balık yağı tüketiminin, kuvvetli kavrama gücü ile ilişkili olduğu bulunmuştur. ${ }^{37}$

\section{Vitamin D}

Düşük D vitamini seviyeleri, zayıf kas gücü ile ilişkilidir. ${ }^{38,39}$ Vitamin $\mathrm{D}$ seviyesinin düşük olduğu kişilerde, replasman ile güç ve fonksiyonda artış ve düşme sayılarında azalmalar olduğu gösterilmiştir. ${ }^{40}$ Vitamin D replasmanı, daha az mortalite ile ilişkilidir. ${ }^{41}$ Sarkopenili tüm hastalarda, 25-OH D Vitamin seviyeleri ölçülmelidir. Seviyesi düşük herkes, Vitamin D ile desteklenmelidir.

\section{B) İLAÇ TEDAVÍLERİ}

\section{Anjiotensin-Konverting-Enzim inhibitörleri (ACE inhibitörleri)}

ACE inhibitörlerinin, kas kompozisyonu ve fonksiyonu üzerine direkt olumlu etkilerinin olduğunu gösteren, güçlü kanıtlar vardır. ACE inhibitörlerinin aynı zamanda antienflamatuvar etkileri de bulunmaktadır. Gözlemsel çalışmalar, bu ajanı kullanan bireylerin kas kuvvetinde ve yürüme hızındaki azalmaların daha 1lımlı olduğunu göstermiştir. ${ }^{42}$ Plasebo ile karşılaştırıldığında, ACE inhibitörleri kullanan yaşlı hastaların (6-dakika yürüme testi dahil) fiziksel performans ölçülerinde önemli bir gelişme gösterilmiştir. ${ }^{43}$ Daha düşkün ve yürüme hızı düşük olan, kardiyovasküler sorunları daha fazla olan bireylerin, ACE inhibitörlerinden daha fazla yararlanmaları olasidir.

\section{Statinler}

Statinlerin kas yıkımını önleyebildikleri gibi, endotel fonksiyonunu iyileştirerek kas güçsüzlüğünü ve yorgunluğunu azaltmaları olasıdır. ${ }^{44}$ Statinler ayrıca inflamasyonu azaltarak sarkopeniyi önleyebilmektedirler. Ancak, statin kullanımının iskelet kas kütlesi üzerinde olumsuz etkilerinin de bulunduğu hatırlanmalıdır. ${ }^{45} \mathrm{Bu}$ nedenle statin kullanımı, yaşlı sarkopenili hastalarda sınırlı görülmektedir.

\section{Testosteron}

Testosteron, erkeklerde 35 yaşından sonra yıllık \%1-3 oranında düşmektedir. Kadınlarda ise bu düşüş menopoz sonrası olmaktadır. Testosteronun, anabolik etkileri, protein yıkımını azaltması ve tip I ve II kas liflerinin liflerin boyutlarının artması biçimindedir. ${ }^{46}$ Testosteronun aynı zamanda travmatik hasar sonras1, sinir rejenerasyonunu destekleyen motor nöron üzerinde de olumlu etkisi vardır. Ancak, testosteronun klinik kullanımını prostat kanseri, artan kardiyovasküler olaylar, periferal ödem, kadınlarda virilizm, prostat hiperplazisi, polisitemi ve uyku apnesi gibi yan etkiler nedeniyle sinırlıdır. ${ }^{47,48}$ Kas gücünü artırmak için, düşük serum testosteron düzeyine sahip erkeklerde testosteron kullanımı önerilmektedir. ${ }^{47}$

\section{Östrojen}

Östrojen seviyesinin düşük olması, kadınlarda kas kütlesi azalması ve osteoporoza neden olmaktadır. Hormon replasman terapisi ile tedavi edilmesinin mümkün olduğu bildirilmektedir. ${ }^{48}$ Tedavinin yan etkileri arasında, kanser gelişimi ve venöz tromboembolizm sayılmaktadır. ${ }^{49}$

\section{Dehidroepiandrosterone (DHEA)}

Yaşlı erkek ve kadınlarda yapılan bazı araştırmalar, DHEA takviyesinin kemik yoğunluğu, testosteron ve östradiol düzeylerini arttırdığını, ancak kas gücü ya da fonksiyonunu etkilemediğini göstermiştir. ${ }^{49}$

\section{Kreatin}

Sarkopeni'nin önlenmesi ve tedavisinde, kreatin kullanımı önerilmektedir. $^{50}$ Orta yaşlı ve yaşlı yetişkinlerde, sarkopeni üzerinde kreatin desteğinin etkisi için kanıt olsa da çelişkili sonuçlar vardır. Örneğin, yaşlılarda kreatin desteği ile kuvvet çalışmalarının kombine edilmesi, kas kütlesi ve gücünü düzeltmiştir. ${ }^{51}$ Ancak başka bir raporda da, kreatin desteği kas kütlesi üzerinde, toplam beden kütlesinde veya üst ekstremite gücünde herhangi bir etki göstermemiştir. $^{52} \mathrm{Bu}$ çelişkili sonuçlar nedeniyle, yaşlılarda sarkopeni tedavisi için kreatin desteği önerilmemektedir. ${ }^{53}$

\section{Selektif Androjen Reseptör Modülatörleri (SARMs)}

SARMs, testosteron tedavisinin potansiyel bir alternafidir. SARMs, kas dokusunda testosteronla ayn sahiptir, ancak gelişmiş doku seçicilikleri nedeniyle aynı yan etkileri yoktur. ${ }^{54}$ Yağsız beden kütlesi, kuvvet ve 
işlevler üzerine etkilerinin çalışmalarda kullanılan ajanın düşük doz olması nedeniyle 1 lımlı olduğu tahmin edilmektedir . Kaslarda agonist ve prostat antagonisti olan, daha güçlü ve seçici SARMs gereksinimi olduğu bildirilmektedir. Yağsız beden kütlesi, kuvvet ve işlevler üzerine etkilerinin çalışmalarda kullanılan dozun düşük olması nedeniyle 1lımlı olduğu tahmin edilmektedir. Kaslara agonist ve prostat antagonisti olan, daha güçlü ve seçici SARMs gereksinimi olduğu bildirilmektedir. ${ }^{55} \mathrm{Bu}$ ajanlar, sarkopeni'nin gelecekteki klinik endikasyonları için önemli bir potansiyele sahiptirler.

Sarkopeni'nin tedavisinde, yararları olduğu düşünlen ajanlar arasında, miyostatin inhibitörleri, ursolik asid, proteazom inhibitörleri, siklofilin inhibitörleri, PGC-1alfa, büyüme hormonu, peroxisome-proliferator-activated receptor- $\boldsymbol{\delta}$ ve 5-aminoimidazol-4-carbokzamide-1-beta-4ribofuranosid gibi ajanlar sayılmaktadır. ${ }^{56,57}$

\section{SONUÇ}

Sarkopeni tanımı ile ilgili, önemli ölçüde bir uzlaşı sağlanmış olsa da, ölçümü ve değerlendirilmesi ile ilgili arayış devam etmektedir. $\mathrm{Bu}$ sendromun, medikal tedavisine yönelik bazı farmakolojik ajanlar deneme aşamasındadır. Toplumumuzda, yaygın görülen ve ağırlıkla yaşlı bireyleri etkileyen bu soruna yönelik, bedensel etkinlik ve beslenmenin düzenlenmesi, öneriler arasında geçerliliğini korumaktadır. Aile hekimlerinin, sahada risk altındaki bireylerin erken tespitinde, bakımlarının sürdürülmesinde ve koordinasyonunda önemli rolleri olabileceği gibi, bu hususta gerek yapacakları ev ziyaretleri, gerekse yeni geliştirilecek olan teknolojilerin uygulamaya konulmasında da önemli katkıları olacaktır.

\section{KAYNAKLAR}

1. Şahin S, Cankurtaran M. Geriatrik sendromlar. Ege Tip Dergisi / Ege Journal of Medicine 2010;49(3):31-37

2. Inouye SK et al. Geriatric syndromes: clinical, research and policy implications of a core geriatric concept. J Am Geriatr Soc 2007;55(5):780-791.

3. Roseberg IH. Sarcopenia: origins and clinical relevance. J Nutr 1997; 127:990S-991S.

4. Morley JE, Baumgartner RN, Roubenoff R, Mayer J, Nair KS. Sarcopenia. J Lab Clin Med 2001; 137:23143.

5. Cesar M, Leeuwenburgh C, Lauretani F, Onder G, Bandinelli S, Maraldi C. Frailty syndrome and skeletal muscle: results from the Invecchiare in Chianti study. Am J Clin Nutr 2006; 83:1142-8.

6. Cruz-Jentoft AJ, Baeyens JP, Bauer JM, Boirie Y, Cederholm T, Landi F, et al. Sarcopenia: European consensus on definiti- on and diagnosis: Report of the European Working Group on Sarcopenia in Older
People. European Working Group on Sarcopenia in Older People. Age Ageing 2010; 39:412- 23.

7. Rolland Y, Abellan van Kan GA, Gillette-Guyonnet S, Vellas B. Cachexia vs sarcopenia. Curr Opin Clin Nutr Metab Care 2011; 14:15-21.

8. Mitchell WK, Williams J, Atherton P, Larvin M, Lund J, Narici M. Sarcopenia, dynapenia, and the impact of advancing age on human skeletal muscle sizeand strength; a quantitative review. Front Physiol 2012; $3: 260$.

9. Halil M, Ülger Z, Arıoğlu S. Sarkopeniye yaklaşım. Hacettepe Tip Dergisi 2011; 42:123-132.

10. Erim Z, Beg MF, Burke DT, de Luca CJ. Effects of aging on motor-unit control properties. J Neurophysiol 1999; 82:2081-91.

11. Thornell LE, Lindstrom M, Renault V, Mouly V, Butler- Browne GS. Satellite cells and training in the elderly. Scand J Med Sci Sports 2003; 13:48-55.

12. Brink M, Wellen J, Delafontaine P. Angiotensin II causes weight loss and decreases circulating insulinlike growth factor $\mathrm{I}$ in rats through a pressorindependent mechanism. J Clin Invest 1996; 97:250916.

13. Schaap LA, Pluijm SMF, Deeg DJH, Visser M. Inflammatory markers and loss of muscle mass (sarcopenia) and strength. Am J Med 2006; 119:9-17.

14. Landi F, Abbatecola AM, Provinciali M, et al. Moving against frailty: does physical activity matter? Biogerontology 2010; 11:537-45.

15. Frontera WR, Bigard X. The benefits of strength training in the elderly. Sci Sports 2002; 17:109-116.

16. Frontera WR, Meredith CN, O'Reilly KP, Knuttgen HG, Evans WJ. Strength conditioning in older men: skeletal muscle hypertrophy and improved function. J Appl Physiol 1988; 64:1038-44.

17. Landi F, Onder G, Carpenter I, Cesari M, Soldato M, Bernabei R. Physical activity prevented functional decline among frail community-living elderly subjects in an international observational study. J Clin Epidemiol 2007; 60:518-24.

18. Landi F, Russo A, Cesari M, et al. Walking one hour or more per day prevented mortality among older persons: results from ilSI- RENTE study. Prev Med 2008; 47: 422-6

19. 2008 Physical Activity Guidelines for Americans. Erişim: http://www.health.gov/paguidelines/pdf/paguide.pdf. Erişim tarihi: 01.05.2016.

20. Sundell J. Resistance training is an effective tool against meta- bolic and frailty syndromes. Adv Prev Med 2011:984683. http://dx.doi.org/10.4061/2011/984683

21. Russell B, Motlagh D, Ashley WW. Form follows function: how muscle shape is regulated by work. J Appl Physiol 2000; 88:1127- 32.

22. Borst, SE Interventions for sarcopenia and muscle weakness in older people. Age Ageing 2004; 33:54855 
23. Fielding RA, LeBrasseur NK, Cuoco A, Bean J, Mizer K, Fiatarone Singh MA. High-velocity resistance training increases skeletal muscle peak power in older women. J Am Geriatr Soc 2002; 50:655-62.

24. Global recommendation on physical activity for health. Erişim:http://apps.who.int/iris/bitstream/10665/44399/ 1/9789241599979 eng.pdf. Erişim tarihi: 21.06.2016.

25. Nelson ME, Rejeski WJ, Blair SN, et al. Physical activity and public health in older adults: recommendation from the American College of Sports Medicine and the American Heart Association. Med Sci Sports Exerc 2007; 39:1435-45.

26. Chodzko-zajko WJ, Proctor DN, Fiatarone Singh MA, Minson CT, Salem GJ, Skinner JS. American College of Sports Medicine position stand. Exercise and physical activity for older adults. Med Sci Sports Exer 2009; 41:1510-30.

27. Morley JE. Weight loss in older persons: New therapeutic approaches. Curr Pharm Des 2007; 13:3637-3647.

28. Milne AC, Potter J, Vivanti A, Avenell A. Protein and energy supplementation in elderly people at risk from malnutrition. Cochrane Database Syst Rev 2009;(2):CD003288.

29. Stratton RJ, Elia M. Are oral nutritional supplements of benefit to patients in the community? Findings from a systematic review. Curr Opin Clin Nutr Metab Care 2000;(3):311-315.

30. Short KR, Nair KS. The effect of age on protein metabolism. Curr Opin Clin Nutr Metab Care 2000; 8:89-94.

31. Brass EP, Sietsema KE. Considerations in the development of drugs to treat sarcopenia. J Am Geriatr Soc 2011; 59:530-5.

32. Katsanos CS, Kobayashi H, Sheffield-Moore M, Aarsland A, Wolfe RR. Aging is associated with diminished accretion of muscle proteins after the ingestion of a small bolus of essential amino acids. Am J Clin Nutr 2005; 82:1065-73.

33. Martone AM, Lattanzio F, Abbatecola AM, et al. Treating sarcopenia in older and oldest old. Current Pharmaceutical Design 2015;21(13) 1715-1722

34. Katsanos CS, Kobayashi H, Sheffield-Moore M, Aarsland A, Wolfe RR. A high proportion of leucine is required for optimal stimulation of the rate of muscle protein synthesis by essential amino acids in the elderly. Am J Physiol Endocrinol Metab 2006;291: E381-7

35. Eley HL, Russell ST, Tisdale MJ. Mechanism of attenuation of muscle protein degradation induced by tumor necrosis factor-alpha and angiotensin II by betahydroxy-beta-methylbutyrate. Am J Physiol Endocrinol Metab 2008;295: E1417-26

36. Sakuma K, Yamaguchi A. Novel intriguing strategies attenuating to sarcopenia. J Aging Res 2012:251217. doi: 10.1155/2012/251217.

37. Robinson SM, Jameson KA, Batelaan SF, et al. Diet and its relationship with grip strength in communitydwelling older men and women: the Hertfordshire cohort study. Hertfordshire Cohort Study Group. J Am Geriatr Soc 2008;56(1):84-90

38. Visser M, Deeg DJ, Lips P. Low vitamin D and high parathyroid hormone levels as determinants of loss of muscle strength and muscle mass (sarcopenia): The longitudinal aging study Amsterdam. J Clin Endocrinol Metab 2003; 88:5766-5772.

39. Montero-Odasso M, Duque G. Vitamin D in the aging musculoskeletal system: An authentic strength preserving hormone. Mol Aspects Med 2005; 26:203219.

40. Bischoff-Ferrari HA, Dawson-Hughes B, Willett WC, et al. Effect of vitamin D on falls: A meta- analysis. JAMA 2004; 291:1999-2006.

41. Autier P, Gandini S. Vitamin D supplementation and total mortality: A meta-analysis of randomized controlled trials. Arch Intern Med 2007; 167:1730 1737.

42. Onder G, Penninx BWJH, Balkrishnan R et al. Relation between use of angiotensin-converting enzyme inhibitors and muscle strength and physical function in older women: an observational study. Lancet 2002;359(9310):926-93.

43. Sumukadas D, Witham MD, Struthers AD, McMurdo ME. Effect of perindopril on physical function in elderly people with functional impairment: a randomized controlled trial. CMAJ 2007; 177:867-74.

44. Aoki C, Nakano A, Tanaka S, et al. Fluvastatin upregulates endothelial nitric oxide synthase activity via enhancement of its phosphorylation and expression and via an increase in tetrahydrobiopterin in vascular endothelial cells. Int J Cardiol 2012; 156:55-6193.

45. Armitage J, Bowman L, Collins R, Parish S, Tobert J. MRC/BHF Heart Protection Study Collaborative Group. Effects of simvastatin $40 \mathrm{mg}$ daily on muscle and liver adverse effects in a 5-year ran- domized placebo-controlled trial in 20, 536 high-risk people. BMC Clin Pharmacol 2009; 31:9-6. doi: 10.1186/14726904-9-6.

46. Ferrando AA, Sheffield-Moore M, Paddon-Jones D, Wolfe RR, Urban RJ. Differential anabolic effects of testosterone and amino acid feeding in older men. $\mathrm{J}$ Clin Endocrinol Metab 2003; 88:358-62

47. Borst SE, Yarrow JF, Conover CF, et al. Musculoskeletal and prostate effects of combined testosterone and finasteride administration in older hypogonadal men: a randomized, controlled trial. Am J Physiol Endocrinol Metab 2014;15(306): E433-42.

48. Siparsky PN, Kirkendall DT, Garrett WE. Muscle changes in aging: understanding sarcopenia. Sports Health. 2014 Jan;6(1):36-40.

49. Baulieu EE, Thomas G, Legrain $S$, et al. Dehydroepiandrosterone (DHEA), DHEA sulfate, and aging: contribution of the DHEAge Study to a sociobiomedical issue. Proc Natl Acad Sci USA 2000; 97:4279-84.

50. Morley JE, Argiles JM, Evans WJ, et al; Society for Sarcopenia, Cachexia, and Wasting Disease. 
Nutritional recommendations for the management of sarcopenia. J Am Med Dir Assoc 2010; 11:391-6.

51. Aguiar AF, Januário RS, Junior RP, et al. Long-term creatine supplementation improves muscular performance during resistance training in older women. Eur J Appl Physiol 2013; 113: 987-96.

52. Cooke MB, Brabham B, Buford TW, S et al. Creatine supplementation post-exercise does not enhance training-induced adaptations in middle to older aged males. Eur J Appl Physiol 2014; 114:1321-32.

53. Onder G, Della Vedova C, Landi F. Validated treatments and therapeutics prospectives regarding pharmacological products for sarcopenia. J Nutr Health Aging 2009; 13:746-56.

54. Mohler ML, Bohl CE, Jones A, et al. Nonsteroidal selective androgen receptor modulators (SARMs): dissociating the anabolic and androgenic activities of the androgen receptor for therapeutic benefit. J Med Chem 2009; 52:3597-617.

55. Cesari M, Fielding R, Bénichou O, Bernabei R, Bhasin S, Guralnik JM, et al. Pharmacological Intreventions in frailty and sarcopenia: Report by the international conference on frailty and sarcopenia research task force. J Frailty Aging 2015;4(3):114-120.

56. Sakuma K, Yamaguchi A. Novel intriguing strategies attenuating to sarcopenia. J Aging Res 2012:251217. doi: $10.1155 / 2012 / 251217$.

57. Burton LA, Sumukadas D. Optimal management of sarcopenia. Clin Interv Aging 2010 Sep 7; 5:217-28. 